Research Article

Yi-ling Pan*

\title{
From Taiwan New Cinema to Post-New Cinema: The Transition of Identity in Cape No. 7 and the Naming Issue of Post-New Cinema
}

https://doi.org/10.1515/culture-2020-0130

received May 11, 2021; accepted October 22, 2021

\begin{abstract}
In 2008, Taiwan's cinema began to get back on its feet after an extended lull, with several directors successively releasing critically acclaimed first works. Compared with the well-known Taiwan New Cinema, this new film trend works within the conventions of genre and often focuses on local issues and ordinary life. In doing so, critics and scholars call it Post-New Cinema. Yet, its naming brings difficulties to our understanding on this epoch-making wave, since it neither intends to innovate the paradigm and the framework established by New Cinema, nor does it completely inherit the legacy left by it. Therefore, these uncertain interpretations motivate us to review the legitimacy of this naming. This essay will evaluate firstly the genealogy from the Taiwan New Cinema to the Post-New Cinema in aesthetic and historical-cultural representation, to further propose the paradox about the naming of Post-New Cinema. Secondly, we attempted, by comparing the two most representative films of the two periods, Cape No. 7 and A City of Sadness, an initial look at the transition and the transformation in terms of aesthetical demonstration, historical representation, and ethnic politics, to argue that a subtle change in identity has been created in Taiwanese cinema since 2008.
\end{abstract}

Keywords: Taiwanese identity, Taiwan New Cinema, Post-New Cinema, postmodern history, locality, Cape No. 7

\section{Introduction}

In 2008, Taiwan's cinema began to get back on its feet after an extended lull, with several new directors successively releasing critically acclaimed first works, such as Chung Mong-Hong's Parking, Tom Lin Shu-yu's Winds of September, and Gilles Yang's Orz Boyz!. However, it took Wei Te-sheng's debut, Cape No. 7, to become a hit at the box office and finally arouse popular interest in Taiwanese film. The film was a spectacular commercial success, pulling in nearly NT\$530 million at the domestic box office, and its reception changed the previously held perception Taiwanese audiences had of domestically produced films as being difficult to understand and hard to enjoy. Indeed, compared with the well-known Taiwan New Wave of the 1980s, best represented by art house directors like Hou Hsiao-hsien, Edward Yang, and the subsequent Tsai Ming-liang, this new film trend has worked within the conventions of the genre, and has often focused on themes of local Taiwanese culture and ordinary life. In doing so, the movement has

\footnotetext{
* Corresponding author: Yi-ling Pan, IETT - Institute of Transtextual and Transcultural Studies, University Lyon 3, Lyon 69007, French Republic, e-mail: yiling.pan10@gmail.com
} 
managed both to turn around a long-depressed film market and make a serious contribution to Taiwanese cinema.

Taiwanese scholars have followed these developments from the beginning and held an international seminar entitled "The 2008 Post-New Cinema Phenomenon in Taiwan" on the subject in 2009 (Peng 124). This seminar focused mainly on film Cape No. 7 and also discussed the other films around 2008. Afterwards, the Film Appreciation Academic Journal also published four seminar papers in an issue entitled "After the New Taiwan Cinema" to discuss the domestic film revival of 2008. Taiwan Post-New Cinema continues to be a subject of discussion today. In 2020, the Centre of Taiwan Studies at the School of Oriental and African Studies (University of London) held an international conference entitled "Taiwan Post-New Wave Cinema." Thus, there appears to be academic consensus that Taiwanese cinema has adopted a new style in narration and created a new aesthetic in presentation in the last decade or so, quite distinct from the Taiwanese New Cinema of yesteryear, and it is called Post-New Cinema.

Indeed, the change in Taiwan Cinema is seen especially clearly after 2008. The distinctiveness of PostNew Cinema can be analysed from both commercial and aesthetic points of view. There are three aspects to the movement as a commercial phenomenon. Firstly, in terms of box-office growth, one or two Taiwanese productions have managed to take in about NT\$100 million in gross revenue every year since 2008 . Compared with the earnings of earlier generations of Taiwanese films, this is a tremendous improvement. This growth in potential earnings has also led to an increase in overall film production, as seen in the number of films released each year: from 19 in 2006 up to 67 in 2016. Secondly, production budgets have grown. Having witnessed the enormous success of Cape No. 7, Taiwanese film producers have sought to invest in and explore different modes of film production, such as blockbusters (e.g. Monga in 2010 and Seediq Bale in 2013), as well as international co-productions (e.g. Black \& White: The Dawn of Assault and Love in 2012). With greater diversity in production, a number of titles have also done well overseas, as in the case of You Are the Apple of My Eye (2011) and More than Blue (2018). The last important commercial aspect of Taiwan Post-New Cinema is its distribution strategy. In the past, films would enter international film festivals and any awards won would be used in promotion campaigns. Today, distributors have various ways of attracting audiences, among them social media and sneak previews, which allow them to pursue greater returns.

From an aesthetic point of view, it can be noted that there has been a shift from art films to genre films, and to films that display a more diverse image of Taiwan than was the case previously. This shift has three principal components, the first being local films. Since 2002, the Taiwanese government has promoted a cultural policy which emphasizes portrayal of ordinary life and local folk culture. Consequently, many films make a point of featuring these themes in order to obtain government subsidies. Examples include $A$ Place of One's Own (2009), Zone Pro Site (2013), and Forever Love (2013). The second component is pan-Asian films, which typically depict Taiwan's links with other Asian countries, Japan in particular. Here, examples include Miao Miao (2008), Somewhere I Have Never Travelled (2009), and KANO (2014). The final component is LGBT (lesbian, gay, bisexual, and transgender) films. From about the year 2000, an increasing number of Taiwanese films have explored LGBT issues, accompanying and testifying to an increasingly emancipatory social atmosphere. Examples include Eternal Summer (2006), Spider Lilies (2007), and Candy Rain (2008). Thus, Post-New Cinema has successfully demarcated itself from the Taiwan New Cinema by two primary characteristics: its penchant for commercial genre film and its exploration of local issues. Furthermore, Post-New Cinema has cast off the historical burden of the Taiwan New Cinema period, associated as it was with heavy going art films, and has struck out on a very different path.

Although recent Taiwanese films have created a unique identity that is different from that of the past, it is still doubtful whether the name Post-New Cinema can be used to define Taiwan Cinema after 2008. At the 2009 seminar held on the topic of "Taiwan Post-New Cinema," film scholar Hong Guo-jun questioned the naming itself. Hong questioned the legitimacy of this naming: In the beginning, it was dubbed "New Cinema" in relation to a specific historical context and definition, but the discursive habits of the past two decades eventually led, it seems, to a kind of nominal ossification, hence the term "Post-New Cinema" (Funscreen no. 233). He also warned that "The notion of 'newness' - implying a severance from the past and promising hope - is extremely tempting and, for that reason, in great need of historicizing” (193). Hong 
argued that we need to re-examine the notion of newness to avoid the failure of the past, because newness does not just mean rupture with the past, as there would be irregular overlaps inevitably between the past and the present (Funscreen no. 233). Hong points out the importance of historicizing, inspiring us to rethink the relationship between the past and the present, and with what historical perspective we ought to employ to define the present.

As a result, in this essay, we attempted to retrace the cinematic genealogy from Taiwan New Cinema (1982-1987) and subsequent periods such as New New Wave in the 1990s to the Post-New Cinema (after 2008), as doing so not only investigates their generative structure between different periods but also helps to clarify the constitutive mode of the present-day Taiwan Cinema. We can employ the "effective-historical consciousness" of Hans-Georg Gadamer as the method to look at the process of Taiwanese cinema between three decades; this involves the sociocultural influence, aesthetical genealogy, and the development of the film industry. In terms of the case study, we choose the film which inaugurated the era of Post-New Cinema, Cape No. 7. Through Cape No. 7 we will argue the aesthetical representation of Post-New Cinema in audiovisual staging and in narrative structure. Furthermore, in order to illustrate the changes of identity at different times, we propose A City of Sadness (1989) of Hou Hsiao-hsien, which is also the most representative film of Taiwan New Cinema, as a reference case. By comparing the character portrayal and the similar historical background between the two films, we can perceive the subtle changes in Taiwanese identity over the past three decades.

On another level, this essay chooses Cape No. 7 as the case analysis not only because of its historical significance to Taiwanese cinema, but also with the intention to initiate a dialogue with, and review of, the 2009 academic journal issue "After Taiwanese New Cinema." Through this same case analysis, it is possible to exhibit the fruitfulness of the Taiwanese academy over the past decade.

\section{The Ghost of Taiwan New Cinema}

Before discussing the Post-New Cinema, it behoves us to investigate what Taiwan New Cinema really was. The emergence of Taiwan New Cinema is from a group of young filmmakers who were liberated from the tired old "formula films" (Yip 56) of before and were able instead to produce films on low budgets, with nonprofessional casts in order to faithfully present the real society of the time and even boldly criticize the government. Most of all, as the other cultural movements during 1970s and 1980s in Taiwan, the filmmakers of Taiwan New Cinema created personal aesthetics in their film language with native consciousness historically presented, thereby successfully leading Taiwanese films to international recognition.

We need, then, to further clarify the historical significance of newness for Taiwanese cinema. There are two sorts of newness which can be viewed from both aesthetic and ideological perspectives. In terms of aesthetic newness, Taiwan New Cinema is mainly influenced by Italian neorealism and especially the French New Wave, which emphasized filmmakers' self-consciousness and thus developed the concept of the auteur. This important cinematic revolution has also influenced many film movements around the world and also influenced the cinema of a number of Asian countries. All of these countries have had their own new waves between the 1960s and 1980s, which suggests an innovative and experimental turn, a desire to break with tradition. It also implies dissatisfaction with the commercial film industry. In terms of ideological newness, Taiwan New Cinema is inspired by the nationalistic cinemas that emerged in Latin America and Africa during the 1960s (Yip 64). In 1987, a group of workers who were associated with Taiwan New Cinema issued a proclamation, declaring their dedication to a new, artistically progressive cinema. They called for the creation of a space outside of the commercial industry for the development of an “'alternative cinema' ... which would seek to make Taiwan the 'center', and focus on addressing the "national'" (Yip 65). Hence, in this context, the newness for Taiwan New Cinema can be regarded as the practice of aesthetical modernity while also conveying the revolutionary spirit against the authoritarian regime. 
Although this cinema revolution only went on 5 years, ${ }^{1}$ Taiwan New Cinema is undoubtedly the most crucial event in history of Taiwan Cinema. Taiwan New Cinema redefined and enhanced the value of Taiwan Cinema, and especially developed Taiwan's national cinema. But it is undeniable on the other hand that Taiwan New Cinema brought about a dark period for the commercial film industry for nearly two decades (Yeh and Davis 56). This is the reason why, after the release of Cape No. 7, many critics finally saw the dawn of a long-awaited recovery and excitedly announced the arrival of the Taiwan Post-New Cinema era. Nevertheless, such a naming is problematic, because the essence of the two is different - New Cinema being auteur cinema and so-called Post-New Cinema being commercial in nature. The Post-New Cinema seeks to call back the public, to re-establish the commercial film industry, and to return to genre filmmaking, yet these were the characteristics that Taiwan New Cinema attempted to overturn in that time.

Apart from this, there were already similar terms being employed such as out/after the New Cinema (Mi-zhou and Liang Hsin-hua edited) or New New Wave of Taiwan Cinema 90's (Chiao) to refer to 1990s Taiwanese films. All these references show that if we still use the name of Post-New Cinema to define Taiwanese cinema after 2008, it may give ambiguity about the chronology and semantics. And more importantly, it will undermine the significant changes such as the terms of the film industries, local culture and identity after 2008 for Taiwanese cinema. So if we still use "post" or "new" for purpose of chronology to demarcate the past, it is simply a redundant term, and such a naming does not characterize the present-day Taiwan Cinema.

In fact, we can see from the title change of the later published Film Appreciation Academic Journal No. 142 from "Post-New Cinema" to "After the New Taiwan Cinema" such reflection on this naming. The editor Kien Ket Lim points out that "the use of the word 'Post' to refer to the 'now' often presents the dilemma of not being able to name the present" (122). Likewise, Peng Hsiao-yen, one of the organizers of "The 2008 Post-New Cinema Phenomenon in Taiwan," also admitted that the success of a particular film such as Cape No. 7 should not be used to determine the coming of a new era: "the so-called 'Post-New Cinema' is still a vague concept" (132). Scholars are thus in a difficult position, anticipating that they will get rid of the past, only to find themselves deeply enmeshed in it.

In the same journal, film scholar Sing Song-yong attempts to solve this naming dilemma. Sing considered that Post-New Cinema is still in a situation where it has not been clearly positioned, because of its secret co-structural relation with history, with the result that Post-New Cinema is not intended to revolutionize Taiwan New Cinema, and intended to establish another cinematographic paradigm using Taiwan New Cinema as its foundation. In Sing's opinion, Post-New Cinema gets rid of the heavy contemplative subjects of before, liberating film from the tragic cause-and-effect relationship of time and space, instead adopting a lighter, "telepathic" mode to bond with the audience (abstract of 2009 seminar). Although the Taiwan New Cinema movement lasted only 5 years, its legacy is deeply embedded in the structure of subsequent film and continues to influence today's filmmakers. This is why it is difficult to define the cinema produced after Taiwan New Cinema in a linear chronology, because the ghost of Taiwan New Cinema continues to linger (141).

In Sing's opinion, the new generation of 1990s Post-New Cinema has already created a distinctive style, as in the works of Ang Lee, Tsai Ming-liang, and Lin Cheng-sheng. On the one hand, this generation inherited the slow aesthetics of Taiwan New Cinema. But on the other hand, they departed from the political and historical themes of Taiwan New Cinema and focus on modern issues such as homosexuality, the family and interpersonal relationships. Moreover, the principal filmmakers of Taiwan New Cinema-Hou Hsiao-hsien and Edward Yang - still released innovative films that incorporated modern issues in the 1990s (141). As a result, 1990s Post-New Cinema can be regarded an another branch of Taiwan New Cinema, as it combined the aesthetics of Taiwan New Cinema with issues of modernity, presenting the urban scape of modernization in Taiwan (especially in Taipei).

1 Generally, In Our Time (1982) marks the beginning of Taiwanese New Cinema, and All for Tomorrow (1987) marks the death of the New Cinema. Reference of Chapter 4: The Life and Death of New Taiwan Cinema in Taiwan Cinema, A Contested Nation on Screen, Hong Guo-jun, 2011. 
In 2008, a group of new directors focused on different content, with generally light, collage narratives about youth who created their own style of film. Such a change in style comes in part from the diversity of film production. For the past half century, most Taiwanese films have been produced and distributed by the Koumintang's Central Motion Picture Corporation (CMPC), as seen in the Healthy Realism of the 1960s and the internationally acclaimed Taiwan New Cinema. In the end of the 1990s, with the Koumintang increasingly withdrawing from the media ${ }^{2,3}$ and the liberal market, Taiwan's film production has diversified with domestic corporation film production and the investment of multinational funds. In terms of aesthetic, they abandoned the auteur paradigm, thus sweeping away the shadow of the past box-office failures and appearing to signal a changing of the guard. However, the spirit of Taiwan New Cinema can still be seen haunting these new popular films-indeed, these new directors were also trained by Taiwan New Cinema-and enlightening the creativity of these new directors. In one of the scenes in Wide of September, for instance, while the student couples are kissing and touching each other in Movie TV, the screen is showing the scene from Dust In The Wind (Hou Hsiao-hsien 1986), in which there is a scene of the student couples strolling on the railway tracks; the two different scenes of love styles reflect the process of modernization in Taiwan, from a rural community to an urbanized society. Likewise, the student gangs of teenage boys in this film are also reminiscent of the teenage gangs in Edward Yang's A Bright Summer Day (1991). Moreover, unlike the detached relationship between Taiwanese films of 1990s and Taiwan history, the Taiwanese films after 2008 have renewed focus on history, demonstrating a strong native consciousness in their narratives' themes; or showing the local landscape outside the city, all of which can be seen as a return to the spirit of Taiwan New Cinema.

In his essay, Sing also suggests naming "Post - New Cinema" for Taiwanese cinema after 2008, with the dash "-” in this term signifying a link with, and a separation from, as well as a kind of manifestation of Taiwan New Cinema. The elongated dash also ensures that the cinema it refers to is conceptually distinct from the homonymous Post-New Cinema of 1990s Taiwanese film (141-142). Sing's discourse is based on Taiwan New Cinema as a benchmark, which highlights the two-way interrelationship between Post-New Cinema of 1990s and Post - New Cinema of 2008. This co-structure constitution and symbiotic relationship with history is, as Hong Guo-jun said, an irregular overlap between historical passages. More significantly, the Post - New Cinema of 2008 departed from the Taiwan New Cinema in aesthetic but returned to the theme of Taiwan-centred history in narrative, and even reveals the intention of reconstructing Taiwan's history.

Regardless of the Post-New Cinema of 2009 seminar or the Post - New Cinema proposed by Sing Songyong, both of these names are based on Taiwanese films of 2008, especially Cape No 7. In hindsight, such names as these discussed above were helpful at the time, serving to stimulate thought and discussion as well as foreshadowing the future breakthrough of Taiwanese cinema. However, Taiwanese film has developed over the time since Cape No. 7. If we still use the term "post" to refer to Taiwanese film today, it implies that the present cannot surpass the past, and so how can we part finally with Taiwan New Cinema? If we imagine Taiwanese cinema to have moved on to another phrase, then it warrants careful scrutiny to investigate whether the development of Taiwanese cinema over the past years has been sufficient to announce the opening of a new chapter of history, and to examine the irregular overlaps between historical transitions.

As mentioned above, we can perceive that many scholars agree on the importance of Post-New Cinema for Taiwan Cinema, which has not only changed the mode of Taiwan's domestic-produced films, but has even re-cinematized it. However, whether the term Post-New Cinema can be used to define the present-day Taiwan Cinema requires a more complete and deeper argument. This essay returns to Cape No. 7, the

2 The withdrawal of the government from the media was a social movement and policy in Taiwan after the 1990s, starting with the "Party, Government and Military Withdrawal Campaign" (黨政軍退出媒體) initiated by many civil society organizations in 1995. Since 2003, legislation has been completed to end the monopoly and control of the media by the Kuomintang. Reference from 莊春發, “論以市場結構為基礎規範黨政軍退出媒體的適當性”, Chinese Communication Society, 2011, p. 4. 3 In 2005, Kuomintang withdrew from the management of CMPC. Reference from official site of CMPC. 
beginning of Post-New Cinema in 2008, as an example. Through Hans-Georg Gadamer's "historically effected consciousness" (wirkungsgeschichtliches Bewuss) concept (300-301), we contrast the transformation of Taiwanese identity between Cape No. 7 and City of Sadness in different contexts, in an attempt to find the historicity of "fusion of horizons" by highlighting the conversation between the text and historical context (390).

\section{Postmodern Representation of History}

As the best-selling film in the history of Taiwanese cinema, Cape No. 7 combines the elements of commercial cinema and portrays the life of the ordinary people in today's Taiwan, which makes Taiwanese audiences feel an affinity; its cross-generation love story has also touched their hearts. However, the success of Cape No. 7 is not only the milestone of commercial cinema, but also in its unique narrative approach that presents a postmodern representation of history. The story of Cape No. 7 is closely interconnected by two storylines: one is the modern story about Aga, who returns to his hometown Hengchun because of the failure of his music career in Taipei. He gradually begins a new life there, gets a job as a postman, and organizes a band with local residents. He also falls in love with a Japanese woman, Tomoko. The other storyline follows a pair of Taiwanese and Japanese lovers in the Hengchun of 1945. One of the lovers, a Japanese teacher, broke his promise to meet his Taiwanese student counterpart, also called Tomoko, at the last minute leaving her alone at the port. On his trip back to Japan, the teacher turns this guilt into seven unsent love letters.

The two storylines seem to be unrelated, but while delivering letters one day, Aga the postman comes across these seven love letters, the sending of which has been delayed for six decades, thus creating an unexplained but profound connection between these two cross-culture love stories. Although the length of 1945 storyline (about $15 \mathrm{~min}$ ) is much shorter than the modern storyline, we can see the love letter is the motif of the film. The seven love letters are interposed sequentially by the Japanese teacher's voice-over (in Japanese) during the film, which drives the plot. From the Japanese monologue of the opening, it created a mysterious and nostalgic tone for the film. Whenever the voice-over, with the melancholy music, narrates the teacher's feelings of regret at leaving the Taiwanese student, Tomoko, we are shown images of Aga and the Japanese Tomoko in the present - Tomoko strolling wistfully on the beach and Aga cycling through the alleys in Hengchun and so on, amid the Hengchun's daily life. In their depiction of everyday life overlaid with a voice from the past, these audio-visual juxtapositions not only evoke a sense of nostalgia, but more importantly, they tie together the two storylines - representing the past and present - intertextualizing them, and further making the seven love letters from 1945-symbolic of something that is gone and irrevocable - become instead a source of renewal, giving the present-day lovers a historical significance.

These seven love letters can be seen as a symbol of transitional time. In terms of the narrative structure, in the moment when Tomoko finds the undelivered love letters in Aga's room, in this moment, a connection is made between two different times, which also functions as a key twist in the advancement of the storyline. Firstly, after reading the letter, Tomoko releases her defences and openly faces her feelings for Aga. Together, the two of them deliver the letters to old Tomoko Kojima. Secondly, and more importantly, when the lovers of the present-day narrative face their own moment of farewell, they recognize the regret of the past story, which is why afterwards Aga says to Tomoko: "Stay, or I'll go with you." This single sentence takes the place of the thousand-word confessional love letter written by the Japanese teacher, and in a sense makes up for the unhappy ending of the parallel love affair that took place all those years before. Further to the point, Aga sings a self-composed song in the concert that follows, of which one of the lyrics is: "I'll try to finish the love story in the past." This line also demonstrates the continuity of the relationship between the present lovers and the past. Hence, the love letters not only become in themselves a symbol of transitional time, linking two different time periods, but they also signify the inspiration of the past history to the present time. 
On the other level, the voice-over of love letters conveyed also the significance in terms of aesthetic. On the one hand, this audio-visual juxtaposition in the presentation of the love letters deepens the impact of the story. As the plots develop, each time the voice-over is interposed with the music, it is gradually deepening the plot impact and increasing the effects in melodrama. On the other hand, this staging blurs the boundary between the past and the present, that incarnate concept of history which is proposed by Walter Benjamin, so-called Jetztzeit, means "time of the now." For Benjamin, "History is the subject of a structure whose site is not homogeneous, empty time, but time filled by the presence of the now [Jetztzeit]" (261), which means to imagine time as a canvas of stars, the task of the historians being the identification of constellations among them, in order to seize hold the meaning given by history from the fragments of history. Benjamin proposes another way to look at history, which emphasizes an interventionist view of history. His vision indirectly influenced the subsequent school of New Historicism in the 1980s, which in turn evolved into a postmodern view of history (Chu). Back to Cape No. 7, Aga and Tomoko, in the beach scene near the end, recognize the Jetztzeit in history, further intervening their own history in an active way. This scene not only exactly demonstrates the climax of a melodrama, but it also embodies the proactive approach to history in the postmodern view of history.

Other characters in the film also demonstrate this proactive approach to history in the way of alltagsgeschichte (which means the daily life of each individual). As like Benjamin said: "Not man or men but the struggling, oppressed class itself is the depository of historical knowledge" (260). Cape No. 7, by portraying the daily life of residents, like the roles Old Mao, Rauma, Frog, Malasun, and the town council representative, they manifest "to brush history against the grain" of Benjamin (257), refusing to let the lives of ordinary people be buried by the mainstream values of historicism. Ordinary people like these are increasingly forgotten, due to the urban-rural divide caused by Anglobalization, ${ }^{4}$ the imperialism of the capitalist, ${ }^{5}$ as those who belong to a marginalized group in contemporary society. However, when the foreign corporation bought up and developed their land, resulting in a sense among the townsfolk that they were losing their culture, they did not submit meekly to company representatives who promised progress in exchange for the loss of their way of life, but instead struggled in order to make their voices heard. In the film, the town council representative sees his hometown losing its identity as a result of globalization and he fights to allow residents to perform in commercial concerts at the hotel developed and run by the foreign corporation. In the end, the performance by the under-appreciated amateur band brings the film to its final climax, which especially demonstrates again the agency in history of the postmodern historical view.

If we contrast Cape No. 7 with the film of Taiwan New Cinema, City of Sadness, we can remark more clearly about this postmodern agency. In terms of historical narrative, both films show the impact of the new historicism and postmodernism in Taiwan after the lifting of martial law in 1987, that is, presenting another history through the perspective of the ordinary people. In terms of plot, both of them share a similar historical background: the evacuation of Japanese troops from Taiwan in 1945, after World War II. In addition, both films also depict the failed love story between Japanese and Taiwanese lovers, and the sufferings of ordinary Taiwanese people in the era. In terms of narrative structure, both films also make extensive use of private letters transformed into the public voice-over. In City of Sadness, Hou Hsiao-Hsien presented his renowned slow aesthetic. By using medium and long shot, calm female voice-overs and the historical representation of Chen Yi's voice through radio, they document the historical events in Taiwan from 1945 to 1949, portraying the persecuted Taiwanese people under the Kuomintang during the February 28th Incident, thereby questioning the official history. Compared to City of Sadness, which uses realistic cinema language to present history and narrate the sorrow and helplessness of the Taiwanese people under the Koumintang's hegemony, Cape No. 7 uses instead comedy style and melodramatic music to introduce

4 Niall Ferguson considers the US to be the sole candidate for resuming the burden once borne by Britain of "imperial globalization.” Reference from Callinicos's Imperialism and Global Political Economy, p. 14.

5 For D. Harvey, "Imperialism of the capitalist sort arises out of a dialectical relation between territorial and capitalistic logics of power. The two logics are distinctive and in no way reducible to each other, but they are tightly interwoven.” Reference from Callinicos's Imperialism and Global Political Economy, p. 155. 
Taiwan's contemporary society and bring out a love story in the history. In other words, the difference between Cape No. 7 and City of Sadness is that instead of presenting significant historical events, Cape No. 7 transforms them into a highly affective melodrama. Most importantly, the status of the ordinary people characters in City of Sadness has been transformed into a positive and proactive position in Cape No. 7, as these ordinary people characters fight against (or coexist with) capitalism under globalization, and they are shining brighter than ever.

\section{Postcolonial Representation of Politic}

City of Sadness does not share the same context as the characters in Cape No. 7 - one is the violent event under an authoritarian regime, the other is the cultural crisis and economic exploitation under globalization. But there is a question worth exploring, that is, what drives the characters in Cape No. 7 to rise up against the imperialism of the capitalist?

Appadurai, in his essay "Grassroots Globalization and the Research Imagination" mentioned the concept of "globalization from below." Appadurai considers that with the increasing development of media transmission, it has helped the place-based imagination to the ordinary people. He said: "The imagination is no longer a matter of individual genius, escapism from ordinary life, ... It allows people to consider migration, resist state violence, seek social redress, and design new forms of civic association and collaboration, often across national boundaries" (6). Therefore, Appadurai encouraged the social form from below, to flow the disjunctive of social wellbeing and reach an emancipatory politics under globalization through the imagination in social life. This radical politics concept inspired Kuei-fen Chiu, the Taiwanese scholar, to discover "Taiwaneseness." For Chiu, the Taiwaneseness means the coexistence of modernity and locality. In the context of globalization, Taiwaneseness builds its own political significance through the local imagination and grassroots culture (46-47). In Cape No. 7, the international hotel will organize a concert which only invites the foreign performers, but the town council representative opposes this decision, due to which the locals become invisible. Thus, the representative tries to persuade the multinational enterprise to include a band formed by the local residents. The representative opposes the exclusive use of local resources by multinational corporations, but instead of refusing the entry of capitalism, he changes his strategy, to coordinate with capital corporates; this plot is in line with Appadurai's "globalization from below" and further demonstrate the coexistence of Taiwaneseness. The manifestation of locality highlights the difference between the Post-New Cinema and Taiwan New Cinema, which even to some extent influenced the transformation of Taiwanese identity under the accelerated globalization after 2000.

Sinophone studies is a novel theory which can furthermore put Taiwan's locality into the system of globalization, not only to help Taiwan to reconsider its own complex histories, but also to culturally deepen Taiwan's ties with other allies. The term Sinophone was first coined by scholar Shih Shu-mei in 2004 to refer to Chinese language cultural groups outside of China (i.e. Hong Kong, Taiwan, Singapore, Malaysia), as well as to minority groups within China (i.e. Tibet, Xinjiang, Inner Mongolia). After years of discussions among scholars, the field of Sinophone studies has evolved beyond its original field of inquiry to become a multidisciplinary area covering language, ethnicity, literature, culture, gender, and art. Sinophone studies is influenced by postcolonial studies, which highlight particular colonization contexts and attend to the historical traces left after those colonies attained independence. The concept of the Sinophone is thus mainly understood in terms of postcolonial theory; Shih has adapted this so that the concept of the colonial context could be used in the Sinophone countries.

According to Shih's theory, there are three parts to the historical formation of the Sinophone. The first is so-called continental colonialism, which refers to present-day China. Shih defines China as an Inner Asian empire. The present-day China has inherited the territory of the Qing dynasty and expanded constantly from 1949 (Shih, "What is Sinophone studies?" 3). The second part is settler colonialism, which refers to the communities and places outside China dominated by Han immigrants, such as Taiwan and Singapore. Through her discourse, Shih tries to oppose the idea of the Chinese diaspora, arguing that Han settlers 
should be given the opportunity to become localized, integrating the self with the culture of the place they inhabit, instead of thinking of China as their homeland (6). The last part has to do with "(Im)migration," 6 which refers to the Han who have immigrated around the world (focusing especially on those in Western countries). To Shih, even though these immigrants appear to feel very strong nostalgia for China, Sinophone culture is place-based and belongs to the place where it is produced (7).

Shih's arguments take an antagonistic stance that excludes mainland China, for which Sinophone studies has been criticized and is controversial, but it has evidently opened up a novel approach to Taiwanese studies. On the one hand, the antagonism of excluding China from Sinophone study has similarities to Appadurai's radical politics philosophy, which can help the disadvantaged Taiwan confront the powerful China in international diplomacy. On the other hand, Sinophone studies emphasize that the place-based establishment of immigration is also consistent with the locality of Taiwaneseness. Therefore, the application of Sinophone studies to Taiwan can not only help in grappling with the special colonial history of Taiwan, but also help it to establish its own uniqueness and place-basedness (Shih, Against diaspora 135).

We can see both the characteristics in Cape No. 7. The Japanese voice-over not only evokes the memories of the Japanese period which was suppressed during the Koumintang's 60-year-long hegemony. By displaying the forgotten memories, Taiwan is able to establish its historical uniqueness and gradually detach itself culturally from the dependence on "homeland China." In addition, Sinophone studies is distinctive in being a de-centred theory that emphasizes multidirectional critique, periphery-againstcentre, and place-basedness. In the final concert, for instance, the energy of the place-basedness (same with locality) was demonstrated when Aga lifts up the loudspeaker and raises a voice that had not been heard in Taipei. Another way in which the film lends itself to Sinophone analysis is in the beginning of the film, when Aga leaves the capital city, Taipei, riding his motorcycle southwards to a small town on the edge of Taiwan. This spatial movement demonstrates one of the subjects of the film, namely leaving the centre and going to the periphery. Likewise, this opening declared the shift of Taiwan Cinema from 1990s PostNew Cinema (to the early 2000s), with the background set often in the modern city Taipei, to contemporary cinema with an emphasis on the locality.

A paper written by Minxu Zhan for "The 2008 Post-New Cinema Phenomenon in Taiwan" seminar also discusses this confrontation. Zhan considers the way in which Cape No. 7 uses Japanese symbols to construct a unique hybrid Taiwanese culture, with the intention to confront Chinese culture from the perspective of Sinophone studies (177). However, on the other hand, Zhan argues that this strategy of setting locality and Chineseness in a dichotomy does not help us to consider the complexity of Chinese cultural inheritance, and not only oversimplifies Taiwan's complex history of multiple colonizations, but also prevents us from understanding the unique geopolitical position of Taiwan (178, 181). Zhan also considers the depiction of locality and ordinary people in Cape No. 7 as not only unnatural, but manipulative, and expresses an ideology of ethnic politics (181). For example, the band of Cape No. 7 can be seen as a metaphor for Taiwan's ethnic relations, but waishengren (expatriated mainlanders), who would represent Chinese culture, are absent. Zhan's critique echoes David D. W. Wang's discourse of post-loyalism which contrasts Sinophone studies (19). Wang considers Shih's "against diaspora” perspective to be too idealistic and to deny the fact that Chinese culture remains as important as it is to Chinese overseas communities because they face difficulties in integrating into their new societies. Coincidentally, both Zhan and Wang point out that the complexity behind history and the entanglement of ethnic politics cannot be distinguished by a simple dichotomy.

However, if we put Cape No. 7 into the context of Sinophone studies, we could understand the absence of waishengren to serve a similar purpose to the exclusion of China from Sinophone studies. This point of such exclusions is to retain its critical energy in opposing the centre, to create a certain reciprocal tension, to criticize Chinese-centrism on the one hand, and to construct itself through its place-basedness and uniqueness on the other (Shih, Against diaspora 135). By the same token, by using radicalism as a discursive

6 The historical process of "Emigration, migration, and immigration" from China (13). 
strategy, we can consider further why waishengren are absent from this film. The point is not to simplify Taiwan's complex colonial history or to intensify a sense of ethnic opposition, but to emphasize that Taiwan is still in a state of non-decolonization and that the Kuomintang regime continues to suppress the richness of Taiwanese culture, even after the change of the ruling party. We have to rethink whether Taiwan's socalled Chinese culture is an organic cultural legacy or a political violence that has yet to be sifted through and dealt with.

Chris Berry also noted that if there is another absence in Cape No. 7, it is the absence of China. Berry points out every other ethnic group, including Western tourists, is represented in the film, but not mainland Chinese. Thus, he considers that the absence of any reference to China as a structuring absence (119). He suggests also that this structuring absence reflects the politic circumstances between Taiwan and China at the time. China, as like a big Other, pressing strongly on the consciousness on Taiwanese people (120). In the final concert of Cape No. 7, when Aga sang the German folk song Heidenröslein with the Japanese singer, their duet demonstrates the nostalgia of colonial Japan and another imagination of identity. Hence, depiction of this less-often-seen side of Taiwan is perhaps the only way-through the absence of Chinese elements - to reveal neglected parts of its culture and histories that, to some extent, have been forgotten.

\section{Conclusion}

Since 2008, the development of local film industries has stabilized the domestic box office and successfully opened up overseas markets. The combination of commercial elements and local culture has not only restored Taiwanese people's confidence in Taiwanese cinema but also produced subtle changes in Taiwanese identity. Through the example of Cape No. 7, on the one hand, it is possible to see how present-day Taiwanese cinema has introduced historical events into commercial films to make it easier for the public to understand the past history of Taiwan and, on the other hand, it also shows how the local Taiwanese people have displayed more agency under globalization, seeking to coexist with transnational capitalism. In addition, the absence of Chinese elements in Cape No. 7 is analysed from the perspective of Sinophone studies, showing that the Taiwanese people are seeking an alternative outlet for their identity in the midst of China's rise.

However, we cannot lose sight of the fact that the international reputation of Taiwanese cinema has been gradually fading in recent years, and this is an issue that Taiwanese cinema must face today. Furthermore, whether the success of commercial cinema can really bring Taiwanese cinema to a different phase, or whether it will regress back to the era before Taiwan New Cinema and become complicit with the imperialism of the capitalist - another ideological manipulation - remains to be seen. Likewise, with the development of overseas markets, is it possible to avoid political criticism in order to take into account the Chinese market? If the critical spirit of Taiwan New Cinema is lost, can it still be called Post-New Cinema? For that reason, we need to be more cautious about the naming of Post-New Cinema, because it may cause the current Taiwanese cinema to overlook some potential problems.

Acknowledgment: I am grateful to the anonymous reviewers for the comments and suggestions. I would like also to express my special gratitude to the editor, Jonl solomon, for his painstaking help and translations advices.

Conflict of interest: Author states no conflict of interest. 


\section{Works Cited}

Arjun, Appadurai. “Grassroots Globalization and the Research Imagination.” Public Culture, vol. 12, no. 1, 2000, pp. 1-19. Benjamin, Walter. "Theses on the Philosophy of History." in Illumination, edited by Hannah, Arendt, trans by Harry Zohn, Harcourt, 1968, pp. 253-264.

Chris, Berry. “Imagine There's No China:Wei Te-sheng and Taiwan's 'Japan complex’.” Taiwan Cinema: International Reception and Social Change, edited by Kuei-fen Chiu, Ming-yeh T. Rawnsley and Gary D. Rawnsley, Routledge, 2017, pp. 111-121. Callinicos, Alex. Imperialism and Global Political Economy, Polity, 2009.

Gadamer, Hans-Georg. Truth And Method, translated by Joel Weinsheimer and Donald G. Marshall, 2nd ed., Crossroad, 2004. Hong, Guo-jun. Taiwan Cinema, A Contested Nation on Screen, Palgrave Macmillan, 2011.

Shih, Shu-mei, “What is Sinophone Studies?" Sinophone Studies: A Critical Reader, edited by Shu-mei Shih, Chien-hsin Tsai and Brian Bernards, Columbia University Press, 2013, pp. 1-16.

Yip, June. Envisioning Taiwan Fiction, Cinema, and the Nation in the Cultural Imaginary, Duke University Press, 2004. Yeh, Emilie Yueh-yu, and Davis Darrell William. Taiwan Film Directors: Treasure Island, Columbia University Press, 2005.

\section{Chinese}

Chiao, Peggy. New New Wave of Taiwan Cinema 90's, Rye Field Publishing, 2002.

Chiu, Kuei-fen. “'Taiwaneseness' and the Radical Politics of Place-Based Imagination in the Age of Globalization.” Chung Wei Literary Quarterly, vol. 32, no. 4, 2003, pp. 45-65.

Lim, Kien Ket. “Editor's Note.” Film Appreciation Academic Journal, vol. 28, no. 2, 2010, pp. 122-123.

Chu, I-hsien. "Postmodern Historiography." English Literature and Culture Teaching Database, May 2007, http://english.fju. edu.tw/lctd/List/ConceptIntro.asp?P_No=\&C_ID=217.

Mi, Tsou and Hsin-hua Liang, eds. Out/after the New Cinema, T'ang-shan Publications, 1994.

Peng, Hsiao-yen. “Cape No. 7: A Surprise Hit?: Looking Back On Taiwan New Cinema." Film Appreciation Academic Journal, vol. 28, no. 2, 2010, pp. 124-136.

Sing, Song-yong. "The Telepathy in Downgrading History: On the Fluid Imaging of Taiwan's 'Post - New Cinema'." Film Appreciation Academic Journal, vol. 28, no. 2, 2010, pp. 137-156.

Sing, Song-Yong. (孫松榮)〈輕歷史的心靈感應: 論台灣「後-新電影」的流體影像學〉conference abstract of The 2008 Post-New Cinema Phenomenon in Taiwan (美學與庶民 : 2008台灣『後新電影』現象), 29-30 October 2009, https://www.yumpu. com/xx/document/read/35933536/2008-.

Shih, Shu-mei. Against Diaspora: Discourses on Sinophone Studies, Linking Publishing, 2017.

Tsang, Chi Kwan. (曾芷荺)〈層層揭開「後新電影」的面紗：洪國鈞教授談台灣電影史〉Funscreen no. 233, 12 November 2009, http://www.funscreen.com.tw/headline.asp?H_No=273.

Wang, David D. W. “What is Sinophone? (什麼是華夷風?).” Sinophone. edited by Yu-lin Lee, Linking Publishing, 2020, pp. 9-34.

Zhan, Minxu. "The Making of Grass-roots Taiwan's Imagination in Cape No. 7." Film Appreciation Academic Journal, vol. 28, no. 2, 2010, pp. 170-184. 